\title{
Undergraduates' Use of Social Media as Information Sources
}

\section{Kyung-Sun Kim, Sei-Ching Joanna Sin, and Eun Young Yoo-Lee}

\begin{abstract}
Social media have become increasingly popular among different user groups. Although used for social purposes, some social media platforms (such as Wikipedia) have been emerging as important information sources. Focusing on undergraduate students, a survey was conducted to investigate the following: (1) which social media platforms are used as information sources; (2) what are the main reasons for using these social media platforms for information seeking; and (3) what kinds of actions are taken to evaluate the quality of the information gained from such sources. The study provides a snapshot of current trends in terms of the use of social media as information sources. It also sheds lights on the actions that the undergraduate students took to evaluate information from social media, including social networking and video sharing sites that have rarely been studied previously. Based on the findings, suggestions are made for information literacy programs and roles of librarians and educators.
\end{abstract}

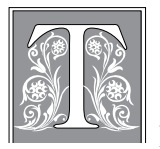

oday, users can access information through a wide range of channels and sources. Research shows that some social media platforms, such as Wikipedia and YouTube, have emerged as important information sources. ${ }^{1}$ It has also been found that more than 50 percent of online teens, and more than 80 percent of college students, use social media for their academic as well as their everyday-life information-seeking purposes. ${ }^{2}$

Unlike traditional information sources, the information available through social media is created and shared by interested users. Because it undergoes little scrutiny, the quality of the information gained from social media varies widely. The prevalent use of social media, despite quality concerns, has triggered a debate over whether or not the critical evaluation of social media sources should form an important part of information literacy (IL). ${ }^{3}$

As social media are becoming increasingly popular information sources, it is important to understand which social media platforms are being used to meet various kinds of information needs, and to understand what actions are being taken to evaluate the

Kyung-Sun Kim is Associate Professor in the School of Library and Information Studies at the University of Wisconsin-Madison; e-mail: kskim@slis.wisc.edu. Sei-Ching Joanna Sin is Assistant Professor in the Division of Information Studies of the Wee Kim Wee School of Communication and Information at Nanyang Technological University; e-mail: joanna.sin@ntu.edu.sg. Eun Young Yoo-Lee is Associate Professor in the School of Library and Information Sciences at North Carolina Central University; e-mail: eunyoung@nccu. edu. (C) 2014 Kyung-Sun Kim, Sei-Ching Joanna Sin, and Eun Young Yoo-Lee, Attribution-NonCommercial (http://creativecommons.org/licenses/by-nc/3.0/) CC BY-NC 
information from such sources. This study therefore examines what undergraduate students do when trying to find information through social media. Research questions include: (1) Which social media platforms are used as information sources; (2) What are the main reasons for using these social media platforms for information seeking; and (3) What kinds of actions are being taken to evaluate the quality of the information gained from such sources. This study will help better understand the current pattern of using social media as information sources. It will also provide suggestions for IL education, as well as roles of librarians and educators.

\section{Literature Review}

\section{Social Media Use}

Social media are defined as "forms of electronic communication (as Web sites for social networking and microblogging) through which users create online communities to share information, ideas, personal messages, and other content (as videos)." ${ }^{4}$ While there are different ways to categorize social media, its typology is often based on the main function and purpose of use, such as for blogging, microblogging (such as Twitter), social networking (for instance, Facebook), collaborative knowledge production and sharing (like Wikipedia), multimedia sharing (example: YouTube), and sharing reviews and opinions (such as social Q\&A, user reviews).

The advent of social media has brought about significant impacts on daily life, not only changing the ways in which people stay connected but also presenting considerable opportunities and challenges for librarians and educators. ${ }^{5}$ It is already known that social networking sites (SNS) such as Facebook are widely used; in fact, about 66 percent of online adults use SNS. ${ }^{6}$ College students are particularly heavy users of social media. ${ }^{7}$ For example, one 2011 Pew report found that over 80 percent of the college students surveyed used SNS. ${ }^{8}$ With the increasing popularity of social media, librarians have actively leveraged these online forums to communicate with users and to reach out to potential audiences. ${ }^{9}$ Some librarians have also explored ways to use social media for teaching IL skills. ${ }^{10}$

In addition to affecting communication, marketing, and instruction, social media seem to have changed students' information-seeking behaviors. Some studies suggest that students may be using various social media platforms to satisfy their academic and everyday-life information needs. ${ }^{11}$ Such changes in information-seeking behavior make it increasingly urgent to understand students' evaluation and use of information obtained from social media. Therefore, the time seems ripe to review (and potentially expand) the scope of IL education to include different media and contexts. In turn, this may further increase the value that librarians can bring to their students' education and lifelong learning.

Like open Web resources, the use of social media as an information source is of concern to IL librarians and educators, in part due to the varying quality of the information available via these media. ${ }^{12}$ User preference toward Web resources has drawn considerable attention from librarians in the past decade and has led to IL programs covering Web source evaluations. ${ }^{13}$ Social media, however, may bring additional challenges to information evaluation when compared to traditional Web resources. Quite a few social media platforms, such as the microblogging platform Twitter, have intentionally limited the length of messages that can be transmitted (for example, 140 characters for each Twitter message). Messages sent out via SNS also tend to be short as well as informal. These may contribute to fragmented information that lacks details or context, which can complicate the evaluation of information quality. Furthermore, many social media platforms, including video sharing sites like YouTube, lack important cues such as citations that students typically use when evaluating scholarly resources 
or traditional Web resources. All of these factors make it challenging to evaluate the quality of the information gained. ${ }^{14}$

In addition, partly due to the ease of forwarding messages with a single click, information can be forwarded almost instantly via one's social networks. Undiscerning social media users may therefore unwittingly contribute to the spread of misinformation. Rumors and inaccurate information can quickly and easily be distributed to a large number of users worldwide. ${ }^{15}$ Seeing the same information on many sites, and being posted by many different individuals, unsuspecting readers may misjudge the information as being credible.

While raising some concerns among IL educators, social media also offer exciting opportunities for users. They facilitate interactive and collaborative knowledge production and sharing. Social media can also provide local and current information and serve as outlets for viewpoints and voices that are not typically conveyed by traditional or dominant media outlets. ${ }^{16}$ If used properly and with care, social media can be powerful and transformative tools.

In this day and age, being information literate inevitably involves a level of expertise in navigating a variety of media platforms, evaluating the information obtained from various sources, and effectively disseminating quality information via social media. As with Web resources, the popularity of social media has again prompted the need for reflective discussions about the goal, definition, and scope of IL education.

\section{Technology Changes and Information Literacy}

Changes in technology continually influence IL education. ${ }^{17}$ Recognizing the importance of active and effective engagement with emergent technologies, librarians and educators have made concerted efforts to recast and broaden the scope of IL into critical IL, ${ }^{18}$ IL 2.0,19 media literacy, ${ }^{20}$ and metaliteracy. ${ }^{21}$ Some academic libraries and university information technology units have started to introduce evaluation guidelines, resource portals, and courses related to the use and evaluation of social media. ${ }^{22}$ There is a general consensus that the focus of IL should not be restricted to merely learning technological skills or following a checklist approach. Instead, the focus has shifted to cultivating higher-order critical thinking skills, including the ability to engage with information in a collaborative environment and through different media.

To foster such IL beyond simplistic and technical know-how, librarians have the potential to play an even broader role in students' education. To realize this potential, librarians need to further explore the challenges and opportunities offered by social media in terms of students' information seeking and use. They should also understand the various contexts in which information seeking may occur. Traditionally, IL education in academic libraries has focused on information seeking within an academic context. This is logical, as the dominant tasks and assignments in a university setting are academic in nature. Nevertheless, the importance of IL in cultivating individuals' lifelong learning has long been recognized, as attested by IL standards guides such as the ACRL's Information Literacy Competency Standards for Higher Education. ${ }^{23}$ Therefore, the scope of IL should encompass information tasks both within academic settings and beyond.

Compared to academic or work-related assignments, everyday-life information needs are often poorly defined and thus can be more difficult for an individual to articulate or fulfill. ${ }^{24}$ As the IL field begins to explore information use and evaluation beyond an academic library setting to cover a broader information horizon that includes social media, this can be an opportune time to expand the focus of IL from academic to everyday-life information seeking. Having played a pivotal role in IL education, academic librarians are especially well positioned to provide training in IL for the effective use of various information sources within different contexts. 


\section{Social Media as Information Sources}

To accompany the discussion about the scope and nature of IL education, it will be useful to collect empirical evidence about how students are currently behaving with regard to their use of social media for meeting their academic and everyday-life information needs, as well as with regard to their evaluation of the information gained from such sources.

One of the challenges brought about by the advances in information and communication technologies is the explosion of information sources and channels. ${ }^{25}$ Some studies have investigated students' source selection across a host of information channels in both academic ${ }^{26}$ and everyday-life information-seeking contexts. ${ }^{27}$ Source selection studies in general have revealed that students prefer to use human and electronic sources to get information. These findings suggest that students are likely to turn to social media as information sources, for social media are just as accessible as other online resources and are as convenient and user-friendly as humans. Because these studies are not primarily about social media, however, empirical data with detailed breakdowns of information-seeking behaviors from specific social media platforms and cross-platform comparisons are still in need. More research also needs to be done to find out what social media platforms are being used for meeting various kinds of information needs.

Among different social media platforms, the use of Wikipedia has received a lot of attention. ${ }^{28}$ Research shows that Wikipedia is often consulted for academic tasks, usually in the early stages of the research process. ${ }^{29}$ There is some evidence that students are consulting Wikipedia for everyday-life information tasks as well. For example, in a survey of undergraduate students, Head and Eisenberg found that over 80 percent of respondents used Wikipedia for everyday-life information seeking. ${ }^{30}$ Data about students' usage of other social media platforms is still vague, however. There has been notable interest in the potential for social question and answer sites (social Q\&A), such as Yahoo!Answers or Quora, to assist in collaborative information seeking. ${ }^{31}$ Nevertheless, it is still unknown how many college students are actually using social Q\&A for academic or everyday-life information seeking.

Compared to other social media platforms, SNS have attracted a lot of research attention, but most studies focus on the role of SNS in cultivating social capital, rather than in seeking information. However, Head and Eisenberg find that about 70 percent of SNS usage is for everyday-life information seeking. ${ }^{32}$ Furthermore, a study of international students' acculturation information seeking reveals that SNS are frequently used for such information purposes, whereas social Q\&A sites are used only rarely. ${ }^{33}$ Whether students tend to rely on only a few social media platforms or many for their information seeking remains to be seen.

Being information literate does not hinge on the type of source used but on whether the source consulted fits the intended purpose of the information seeking and nature of the information needs. As such, after surveying which social media platforms are being used as information sources, a subsequent answer to seek is which social media platforms are being used to fulfill various kinds of information needs. For example, are students using a particular social media platform for an overview, for fact checking, or for networking?

Besides the use and purpose of social media, another important aspect that needs to be explored is the strategy used for evaluating the information gained from social media. Evaluation criteria are one of the core areas of information research. Researchers have identified key evaluation criteria such as accuracy, authority, comprehensiveness, and so on. ${ }^{34}$ Further studies have elicited the credibility judgment criteria used in evaluating information from the Web and other social media channels including 
Wikipedia and social Q\&A. ${ }^{35}$ Similar criteria such as logic, verifiability, accuracy, and author expertise are also mentioned in terms of evaluating answers posted on social Q\&A. ${ }^{36}$

Studies suggest that college students who have received IL training are aware of key evaluation criteria, as evidenced in findings where students cited accuracy as being more important than accessibility for academic tasks. ${ }^{37}$ It should be noted, however, that the knowledge of important evaluation criteria is not always translated into action. Students are still inclined to use convenient and easy-to-use sources, even when they cite accuracy as the most important evaluation criterion. ${ }^{38}$ Indeed, there is a proven tendency for them to follow the "principle of least effort," wherein they seek to use accessible materials over quality sources.

Moreover, diligent evaluation of information from Web resources is rarely performed ${ }^{39}$ Research suggests that individuals may rely on heuristics that are based on superficial or peripheral cues, such as the layout of information, rather than a more concerted quality assessment. This is particularly true when a task is deemed to be of lower significance and when the individual is insufficiently motivated..$^{40}$

In light of the abundant literature on evaluation criteria and on the discrepancy between what people know and what they actually do, a different research approach can be explored-namely, asking students directly about what actions they take to assess the quality of the information available via social media. Such knowledge would help identify gaps in information evaluation and would furthermore inform IL training programs.

\section{Study}

\section{Methods}

A Web-based survey was used to collect data. The questionnaire included closed and open-ended questions about how different social media platforms are used and evaluated. Different types of social media covered include Wikipedia, blogs, user reviews, social networking sites (SNS), video sharing sites, microblogs, and social Q\&A sites. Questions about participants' demographics and academic backgrounds were also included. The questionnaire was developed based on extant literature on social media and an exploratory study. ${ }^{41}$ It was finalized after two rounds of pilot testing. A call for participation was distributed using a mass e-mailing service to all undergraduate students in a public university. Participation was voluntary. Upon completion of the data collection, bookstore gift certificates were awarded to randomly selected participants. As the nonprobability convenience sampling method was used in this study, any generalization of the study's findings should be done with caution.

\section{Participants}

Data were collected from a large Midwest public research university with over 40,000 students. A total of 845 undergraduates participated in the study. Among them, 833 questionnaires were complete and used in the data analysis. About 65 percent of the participants were female; the rest were male. Students from all class levels participated, although freshmen were underrepresented: freshmen (5\%), sophomore $(27 \%)$, junior (33\%), and senior (35\%). Participants were from across different disciplines: humanities $(19 \%)$, social sciences (37\%), engineering (13\%), and natural sciences $(31 \%)$.

\section{Results}

\section{Social Media Platforms as Information Sources}

To identify which social media platforms were used as information sources, we asked participants whether they used a particular social media platform for finding/ 
acquiring information: "Do you ever use [name of a social media type] to find/acquire information?" The results are presented in table 1 . Almost all participants $(98.6 \%$; $\mathrm{n}=821$ ) reported using Wikipedia as an information source. Interestingly, SNS, such as Facebook, were another important source of information, with 95.7 percent $(n=797)$ of participants using them. User reviews $(72.1 \% ; n=601)$ and video sharing sites $(69.5 \%$; $n=579)$ were also used to gain information. About half of the participants $(49.8 \% ; n=415)$ used social Q\&A sites. Blogs and microblogs were not frequently used as information sources, with only about 32 percent $(n=270)$ of participants using blogs and 25 percent $(\mathrm{n}=208)$ using microblogs.

\begin{tabular}{|c|l|c|}
\hline \multicolumn{3}{|c|}{ TABLE 1 } \\
\hline \multicolumn{1}{|c|}{ Different Social Media Platforms Used as Information Sources (N = 833) } \\
\hline Rank & \multicolumn{1}{|c|}{ Platform of Social Media } & Percent of Users \\
\hline 1 & Wikipedia & $98.6 \%$ \\
\hline 2 & Social Networking Sites (for example, Facebook) & $95.7 \%$ \\
\hline 3 & User Reviews (such as reviews in Amazon.com) & $72.1 \%$ \\
\hline 4 & Video Sharing Sites (like YouTube) & $69.5 \%$ \\
\hline 5 & Social Q\&A Sites (for instance, Yahoo!Answers) & $49.8 \%$ \\
\hline 6 & Blogs & $32 \%$ \\
\hline 7 & Microblogs (example: Twitter) & $25 \%$ \\
\hline
\end{tabular}

When the frequency of using different social media platforms was analyzed ("How often do you use [name of a social media type]?"), the use of some social media platforms showed a significant gender difference. That is, male students used user reviews $(t=7.528, p<.001)$, video sharing $(t=5.313, p<.001)$, and social Q\&A sites $(t=4.38, p<$ $.001)$ as information sources more frequently than their female counterparts. In addition, a significant difference between under- (freshmen and sophomore) and upper-classmen (junior and senior) was found in the reported use of some other social media platforms. For example, while upperclassmen used Wikipedia more frequently $(t=-4.319, p<$ $.001)$, they tended to use video sharing $(t=2.265, p<.05)$ and social Q\&A sites $(t=$ $2.086, p<.05)$ less often than underclassmen. A regression analysis revealed that the level of Wikipedia use increased as the class level moved up from freshmen through seniors $(p<0.001)$. Significant differences were also found in the use of platforms by different disciplines. Students in engineering used Wikipedia more often than others, especially those in social sciences $(p<.05)$. Students in humanities used video sharing sites more than those in natural sciences $(p<.05)$.

\section{Main Reasons for Using Social Media as Information Sources}

Why do individuals choose to use social media as information sources? We asked participants to name the reasons why they do so and also to rate the listed reasons for using each social media platform. Results are presented in table 2. As expected, Wikipedia was used mainly for getting background information or a quick overview. It seems that the students considered Wikipedia a good starting point to source information. A participant wrote, for example, that Wikipedia was used "just to get background information or quick information. I wouldn't cite Wikipedia, but for my own curiosity, I will use it to find information... In short, it is a decent starting point." The participants used the SNSs to keep in touch with others, get updates/news, and glean the opinions of others. User reviews were sought mostly to get others' opinions 
TABLE 2

Main Reasons for Using Social Media as Information Sources

\begin{tabular}{|c|c|c|c|c|c|c|c|}
\hline Rank & Wikipedia & $\begin{array}{c}\text { Social } \\
\text { Networking Sites }\end{array}$ & User Reviews & $\begin{array}{c}\text { Video } \\
\text { Sharing Sites }\end{array}$ & Social Q\&A & Blogs & Microblogs \\
\hline 1 & $\begin{array}{l}\text { To get } \\
\text { background/ } \\
\text { introductory } \\
\text { information (3.8) }\end{array}$ & $\begin{array}{l}\text { To keep in touch } \\
\text { with others (4) }\end{array}$ & $\begin{array}{l}\text { To obtain } \\
\text { others' opinions/ } \\
\text { comments } \\
(3.86)\end{array}$ & $\begin{array}{l}\text { To obtain } \\
\text { recreational } \\
\text { information }(3.3)\end{array}$ & $\begin{array}{l}\text { To find solutions } \\
\text { to a problem } \\
\text { or how-to } \\
\text { instructions }(3.5)\end{array}$ & $\begin{array}{l}\text { To obtain } \\
\text { others' opinions/ } \\
\text { comments } \\
(3.43)\end{array}$ & $\begin{array}{l}\text { To get updates/ } \\
\text { news } \\
(3.67)\end{array}$ \\
\hline 2 & $\begin{array}{l}\text { To get a quick } \\
\text { overview } \\
(3.76)\end{array}$ & $\begin{array}{l}\text { To get updates/ } \\
\text { news } \\
(3.4)\end{array}$ & $\begin{array}{l}\text { To help make a } \\
\text { purchase decision } \\
(3.8)\end{array}$ & $\begin{array}{l}\text { To find solutions } \\
\text { to a problem } \\
\text { or how-to } \\
\text { instructions (3.2) }\end{array}$ & $\begin{array}{l}\text { To get } \\
\text { background/ } \\
\text { introductory info } \\
\text { (3) }\end{array}$ & $\begin{array}{l}\text { To obtain } \\
\text { recreational } \\
\text { information }(3.38)\end{array}$ & $\begin{array}{l}\text { To keep in touch } \\
\text { with others } \\
(3.44)\end{array}$ \\
\hline 3 & $\begin{array}{l}\text { To check factual } \\
\text { information } \\
(2.8)\end{array}$ & $\begin{array}{l}\text { To obtain } \\
\text { others' opinions/ } \\
\text { comments } \\
(3)\end{array}$ & $\begin{array}{l}\text { To get } \\
\text { background/ } \\
\text { introductory } \\
\text { information (3) }\end{array}$ & $\begin{array}{l}\text { To get } \\
\text { background/ } \\
\text { introductory } \\
\text { information (2.8) }\end{array}$ & $\begin{array}{l}\text { To check factual } \\
\text { information } \\
(2.8)\end{array}$ & $\begin{array}{l}\text { To get updates/ } \\
\text { news } \\
(3.15)\end{array}$ & $\begin{array}{l}\text { To be aware of } \\
\text { popular trends } \\
(3.37)\end{array}$ \\
\hline 4 & $\begin{array}{l}\text { To find solutions } \\
\text { to a problem } \\
\text { or how-to } \\
\text { instructions (2.3) }\end{array}$ & $\begin{array}{l}\text { To be aware of } \\
\text { popular trends } \\
(2.7)\end{array}$ & $\begin{array}{l}\text { To be aware of } \\
\text { popular trends } \\
(2.28)\end{array}$ & $\begin{array}{l}\text { To be aware of } \\
\text { popular trends } \\
(2.6)\end{array}$ & $\begin{array}{l}\text { To obtain } \\
\text { others' opinions/ } \\
\text { comments } \\
(2.7)\end{array}$ & $\begin{array}{l}\text { To be aware of } \\
\text { popular trends } \\
(2.95)\end{array}$ & $\begin{array}{l}\text { To obtain } \\
\text { others' opinions/ } \\
\text { comments } \\
(3.31)\end{array}$ \\
\hline 5 & $\begin{array}{l}\text { To get updates/ } \\
\text { news } \\
(1.78)\end{array}$ & $\begin{array}{l}\text { To get } \\
\text { background/ } \\
\text { introductory } \\
\text { information } \\
(2.2)\end{array}$ & $\begin{array}{l}\text { To check factual } \\
\text { information } \\
(2.26)\end{array}$ & $\begin{array}{l}\text { To get updates/ } \\
\text { news } \\
(2.56)\end{array}$ & $\begin{array}{l}\text { To be aware of } \\
\text { popular trends } \\
(1.5)\end{array}$ & $\begin{array}{l}\text { To get } \\
\text { background/ } \\
\text { introductory } \\
\text { information (2.69) }\end{array}$ & $\begin{array}{l}\text { To get } \\
\text { background/ } \\
\text { introductory } \\
\text { information } \\
(2.53)\end{array}$ \\
\hline
\end{tabular}


and to gain background information to help make purchase decisions. Although the respondents frequently used video sharing sites for recreational purposes, they also consulted these sites to find solutions or how-to instructions: "Usually I use it for entertainment purposes, but sometimes I find how-to's and lectures that I find helpful," a participant explained. Social Q\&A sites were used to find solutions or obtain background information. As indicated in open-ended answers, the respondents seemed to use blogs to obtain the opinions of others, often for recreational purposes (such as fashion, recipes) whereas they appeared to use microblogs mostly to access news (for example, international news, celebrity news).

Different social media platforms were used for similar purposes. To get background information, users tended to consult Wikipedia as well as social Q\&A, user reviews, and video sharing sites. For fact checking, Wikipedia and social Q\&A sites seem to have been used most frequently. To get others' input, user reviews, SNS, blogs, and microblogs were used. Social Q\&A and video sharing sites helped to find solutions or how-to instructions. For updates and popular trends, SNS and microblogs tended to be used.

\section{Evaluating the Quality of Information}

As some social media platforms were used as information sources, we wanted to find out whether participants take any evaluative actions to check the quality of the information gained from these sites. If they do, what kinds of actions do they take? Table 3 provides a list of such actions for social media platforms that are often used as information sources. The list is organized based on the frequency of use; the action listed at the top is the most frequently taken action for the corresponding source.

For Wikipedia, the most popular social media platform used as an information source among participants, individuals reported trying to find cues from the source itself when evaluating the quality of information. That is, they checked several factors, namely: (1) the quality and quantity of links/references provided; (2) the notes on progress/completeness of the article (such as "citation needed"); and (3) the length of the article. In addition, users often consulted external/official sources to compare and verify the content.

When using SNS, on the other hand, many respondents indicated that they did not take evaluative actions. For example, about 59 percent of SNS users reported that they never check to see if sources are properly cited. If interested in checking the quality of information, participants paid attention to others' reactions to the information and also to the author who provided the information. In addition, some typical evaluative actions were taken, such as checking the tone/style of the writing and the quality of the links/ references provided, as well as comparing the information against external sources.

For user reviews, it seems that participants made significant effort to evaluate the quality of information. They tended to pay attention to the reactions that the current review has received (that is, how many other users agree with the current review or find it useful), and also to comparable reviews by other users (in other words, whether the information provided in the current review is consistent with the information in other reviews). They also checked internal cues, including: (1) whether the reviewer was using the product for the same purpose as the reader; (2) the tone/style of the writing; and (3) the date the review was posted.

Those using video sharing and social Q\&A sites seemed to take very similar evaluative actions. For these social media platforms, participants tended to (1) check others' reactions; (2) compare the content with external sources; (3) check the quality of the links/references provided; and (4) check whether sources are properly cited. For video sharing sites, users also checked the quality of the image/video/audio, whereas social Q\&A users checked the tone/style of the writing. 


\begin{tabular}{|c|c|c|}
\hline \multicolumn{3}{|c|}{$\begin{array}{c}\text { TABLE } 3 \\
\text { Top Five Evaluative Actions Taken for Each Social Media Platform }\end{array}$} \\
\hline $\begin{array}{l}\text { Social Media } \\
\text { Platform }\end{array}$ & Evaluative Actions & $\begin{array}{l}\text { Average } \\
\text { Frequency }\end{array}$ \\
\hline \multirow[t]{6}{*}{ Wikipedia } & & $2.6 *$ \\
\hline & Compare the content with external/official sources & 3.1 \\
\hline & Check quality of links/references provided & 2.7 \\
\hline & Check number of links/references provided & 2.53 \\
\hline & $\begin{array}{l}\text { Check notes on progress/completeness (for example, } \\
\text { "citation needed") }\end{array}$ & 2.5 \\
\hline & Check the length of the article & 2.33 \\
\hline \multirow[t]{6}{*}{ Social Networking } & & $2.4^{*}$ \\
\hline & Check others' reactions/opinions & 2.9 \\
\hline & $\begin{array}{l}\text { Check information about the author/poster (for } \\
\text { example, his/her profile) }\end{array}$ & 2.7 \\
\hline & Check tone/style of writing/argument & 2.4 \\
\hline & Compare the content with external/official sources & 2.2 \\
\hline & Check quality of links/references provided & 2 \\
\hline \multirow[t]{6}{*}{ User Review Sites } & & $3.4 *$ \\
\hline & Check the consistency with other reviews & 3.7 \\
\hline & $\begin{array}{l}\text { Check how many other users agree/disagree with the } \\
\text { review }\end{array}$ & 3.5 \\
\hline & $\begin{array}{l}\text { Check whether the reviewer used the product for the } \\
\text { same purpose as yours }\end{array}$ & 3.32 \\
\hline & Check tone/style of writing/argument & 3.3 \\
\hline & Check when the review was posted & 3.2 \\
\hline \multirow[t]{6}{*}{ Video Sharing Sites } & & $2.4^{*}$ \\
\hline & Check quality of images/videos/audio & 2.8 \\
\hline & Check others' reactions/opinions & 2.7 \\
\hline & Compare the content with external/official sources & 2.4 \\
\hline & Check quality of links/references provided & 2.13 \\
\hline & Check whether sources are properly cited & 2.1 \\
\hline \multirow[t]{6}{*}{ Social Q\&A Sites } & & $2.8^{*}$ \\
\hline & Check others' reactions/opinions & 3.3 \\
\hline & Compare the content with external/official sources & 3.1 \\
\hline & Check tone/style of writing/argument & 3 \\
\hline & Check quality of links/references provided & 2.6 \\
\hline & Check whether sources are properly cited & 2.21 \\
\hline
\end{tabular}


To find out how much effort users put into evaluating different social media platforms, the frequency of use of the top five evaluative actions was analyzed and averaged for each social media platform. The type of social media for which users made the most evaluative effort was found to be user reviews (3.4), followed by social Q\&A (2.8), Wikipedia (2.6), SNS (2.4), and video sharing sites (2.4).

It is interesting to note that, although Wikipedia was found to be the most popular information source, participants did not necessarily make the most effort in evaluating the quality of information provided by this source. More evaluative effort was made for user reviews (3.4) and social Q\&A (2.8) than for Wikipedia (2.6). For user reviews, all of the top five evaluative actions were conducted fairly frequently (ranging between 3.2 and 3.7). Social Q\&A had three such actions, with scores ranging from 3.0 to 3.3. Wikipedia had only one action rated above 3.

When using SNS and video sharing sites, participants seemed to make less effort to evaluate the content as compared to other sources. All of the top five evaluative actions for both platforms scored below 3 (that is, less frequent than "sometimes").

Evaluative actions were further analyzed and grouped based on whether users find evaluative cues from inside or outside the source (see table 4). One of the most frequently used actions of evaluation was to consult external sources (including other

\begin{tabular}{|c|c|c|}
\hline \multicolumn{3}{|r|}{$\begin{array}{c}\text { TABLE } 4 \\
\text { Evaluative Actions by Focus }\end{array}$} \\
\hline Focus & $\begin{array}{l}\text { Targeted } \\
\text { Facet }\end{array}$ & Evaluative Actions \\
\hline \multirow[t]{2}{*}{ External } & \multirow[t]{2}{*}{ Content } & $\begin{array}{l}\text { Compare the content with external/official sources (2.7) [4 } \\
\text { platforms]; } \\
\text { Check the consistency with other reviews }(3.7)\end{array}$ \\
\hline & & $\begin{array}{l}\text { Check others' reactions/opinions (3) [3 platforms }] \text {; } \\
\text { Check how many other users agree/disagree with the review } \\
(3.5)\end{array}$ \\
\hline \multirow[t]{11}{*}{ Internal } & \multirow[t]{2}{*}{ Author } & $\begin{array}{l}\text { Check information about the author-for example, his/her } \\
\text { profile (2.7) }\end{array}$ \\
\hline & & $\begin{array}{l}\text { Check whether the reviewer used the product for the same } \\
\text { purpose as the reader (3.3) }\end{array}$ \\
\hline & Content & $\begin{array}{l}\text { Check others' reactions/opinions (3) [3 platforms]; } \\
\text { Check how many other users agree/disagree with the review } \\
(3.5)\end{array}$ \\
\hline & Date & Check when the review was posted (3.2) \\
\hline & Notes & $\begin{array}{l}\text { Check notes on progress/completeness - for example, } \\
\text { "citation needed" }(2.5)\end{array}$ \\
\hline & \multirow{2}{*}{$\begin{array}{l}\text { Physical } \\
\text { Characteristics }\end{array}$} & Check the length of the article/review (2.3) \\
\hline & & Check quality of images/videos/audio (2.8) \\
\hline & \multirow[t]{3}{*}{ References } & Check whether sources are properly cited (2.2) [2 platforms] \\
\hline & & Check quality of links/references provided (2.4) [4 platforms] \\
\hline & & Check number of links/references provided (2.5) \\
\hline & Tone/Style & Check tone/style of writing/argument (2.9) [3 platforms] \\
\hline
\end{tabular}


reviews) to compare the information for consistency. Another related strategy was to check how others reacted to the information provided. Most social media platforms have incorporated features that encourage interactions between the author of the contents and the readers/users. When no other comparable sources are available, reactions from others toward the information provided can offer cues to help users evaluate the quality of the information.

Users also try to find evaluative cues from within the social media source itself. First, users check whether the author seems to be credible. To learn more about the author, users can check the author's profile, which is often presented within the same social media source. Users seem to pay more attention to the information if it is provided by an author who shares similar characteristics with the users themselves. For example, some participants commented that they look for reviews by an individual whose demographic characteristics or intentions of using a product are similar to those of themselves. Second, users check the date that the information was made available; usually, the more recent ones are better. Third, if references are provided along with the information, users check the quality and quantity of the references. Furthermore, checking whether sources are properly cited is also an important strategy. Fourth, notes indicating whether the information is complete can be used as a cue for evaluation. For example, entries in Wikipedia often contain notes/disclaimers related to the completeness or limitations of the information provided (for example: "citation needed"; "The neutrality of this article is disputed"). It seems that users review such notes to evaluate the quality of the information.

Finally, users also check not only the concrete but also the abstract properties of the information. That is, to evaluate the quality of information, users examine its physical characteristics, including the length of the posting/entry and the quality of the images/ videos. In addition, users also check the style or tone of the writing, which can help them to determine whether the author was biased or neutral, logical or illogical, and so on.

\section{Discussion}

The study found that several social media platforms are popular sources of information. For example, more than 90 percent of participants used Wikipedia and SNS as information sources. User reviews and video sharing sites were also used by about 70 percent of participants. These high usage rates lend support to the view that IL librarians should engage with emergent technologies to ensure that students are equipped with the critical metaliteracy skills necessary to assess and use different social media platforms, as these nonacademic sources are already being used, and at increasing rates.

Interestingly, blogs (32\%) and microblogs (25\%) were rarely used for gaining information. In fact, the use of blogs for information seeking has been declining despite their potential as an information source. ${ }^{42}$ The relatively low reported usage of blogs as an information source in this study could reflect this general trend. Microblogs, such as Twitter, were also rarely used information sources. A recent Pew report indicates that Twitter is not widely used among young adults, although there has been a steady increase in its usage. ${ }^{43}$ As an effective tool for disseminating updated information, however, microblogs have the potential to rise in importance as information sources. It might therefore be worth tracking the trend of using microblogs as information sources over the next few years.

It is worth noting that Wikipedia in particular is frequently used as a source of information. Moreover, students in higher class levels used Wikipedia more frequently. This implies that more experienced students regard Wikipedia as a useful information source-even in spite of the discouragement by some faculty, IL professionals, and even Wikipedia's founder Jimmy Wales to use it for scholarly work. ${ }^{44}$ 
As Wikipedia has become one of the most popular information sources among students, ${ }^{45}$ librarians might need to be proactive about this trend. Collaborative reference sources such as Wikipedia do have positive value when used properly. ${ }^{46}$ Given its popularity, it would still be instrumental to teach undergraduates how to effectively evaluate and use the information provided by Wikipedia, while at the same time pointing out that Wikipedia is not very suitable for academic tasks. Furthermore, librarians and educators might want to explore ways for effectively improving the quality of information offered through Wikipedia, such as by encouraging contributions of quality content among themselves. ${ }^{47}$ It might also be helpful if IL education covered strategies for the creation, as well as the evaluation, of quality information so that students can become not only informed consumers, but also valuable creators, of information.

The study shows that students use social media for various reasons. Some of the commonly cited reasons include getting background information, gleaning others' opinions, and finding solutions or how-to instructions. Although social media cannot replace some of the high-quality traditional information resources whose quality is systematically controlled, they can be used to supplement such resources. Social media take advantage of the wide range of experiences and expertise that people have. While their quality varies, social media information sources can provide information that traditional resources cannot efficiently provide. It would therefore be beneficial to acknowledge their usefulness as information sources and to develop IL programs for helping individuals to effectively evaluate and use them.

Findings about the evaluative actions taken for each social media platform were enlightening. As noted above, Wikipedia was found to be widely used by college students. ${ }^{48}$ However, this study revealed that Wikipedia users did not exert as much effort in their evaluation of Wikipedia sources as they did for user reviews or social Q\&A sites. That is, the average frequency of taking different evaluative actions was lower for Wikipedia than it was for user reviews or social Q\&A sites. This might be because Wikipedia is often used as a starting point from which students can gain background information, rather than as the final resource for their assignments. In fact, responses from open-ended questions indicated that many respondents use Wikipedia because they want to find further resources from it. As Wikipedia is easily accessible and offers a quick overview of a topic with useful links and references, students seem to use it first and then consult additional resources to get more in-depth information later. ${ }^{49}$ Perhaps that is why students make less effort to evaluate the quality of information they gain from Wikipedia.

Furthermore, Wikipedia seems to have a production and presentation system that appears to be similar to traditional resources (such as registered contributors, entry formats, corrections by contributors). Students might put more trust in Wikipedia because of such apparent similarities. For user reviews and social Q\&A sites, on the other hand, there is no such coherent format that makes them easy to evaluate. Moreover, contributors' backgrounds seem to vary widely (if they are known at all). Users of such sites would therefore need to make extra effort to evaluate the quality of the information provided. Further studies could test the above hypotheses and examine what factors affect readers' trust toward different social media platforms.

When using social media as information sources, users take various actions to evaluate the information provided. They try to find evaluative cues from inside as well as outside the source. When using external cues, users compare the contents of the source itself with those from external sources. That is, they check the consistency of the information across different sources. Users also check reactions from others. As opposed to traditional information resources, social media usually allow other users to comment on the information that the author has provided and to access such 
feedback easily. While checking others' comments and reactions to the information may seem to be a strategy unique to social media, in principle it is similar to the use of external reviews and critiques when evaluating traditional resources. If IL education were to cover the effective and systematic ways of writing and evaluating reviews, the quality of online reviews would eventually be improved and they would become more helpful to users.

When using cues from inside the source itself, users pay attention to different aspects such as author, date, references, notes on the completeness/limit of the information, and concrete/physical and abstract characteristics of the posting. Many of these cues are similar to what users consider when evaluating traditional information resources. In typical IL education, the key criteria for evaluating the quality of print and electronic academic information are covered. As social media resources are different from traditional resources in terms of their purpose, production process, structure, and media used, it would be helpful for IL education to include a review of the specific features of each social media platform and to address specific actions along with the criteria that should be used for evaluating the quality of the information.

\section{Conclusion}

Focusing on undergraduate students, the study provided a snapshot of current trends in using social media as information sources. The findings shed light on which social media platforms are frequently used as information sources and how the information provided through social media is evaluated and used.

Apparently, undergraduate students tend to use quite a few social media platforms for finding and acquiring information. In addition to applying a few evaluative actions similar to what they use for traditional resources, students seemed to have developed their own strategies (such as checking disclaimer notes) to evaluate the quality of the information accessed through social media. The effectiveness of these strategies has yet to be fully assessed.

As social media resources have features and characteristics different from those of traditional information sources, a thorough evaluation of the information gained from social media requires new approaches and strategies. Therefore, this might be a good time for librarians and educators to redesign current IL education programs. IL programs should be encouraged to cover strategies for the effective evaluation and use of social media as information sources. For this to happen, a set of evaluation criteria as well as a roster of evaluative actions related to the unique characteristics of the various social media platforms will need to be developed. Students should be encouraged to remain vigilant of the shortcomings of social media information. Problems such as the possibility of fake reviews and the speed and breadth with which misinformation can spread should be discussed. ${ }^{50}$ In addition, IL programs can help students to become effective creators, as well as consumers, of information via various types of sources including social media. Students would benefit from training in social media-related fair use and copyright topics, such as the Creative Commons and proper attributions and citations. ${ }^{51}$ Content contribution from librarians and educators should also be valued and rewarded.

Social media's philosophy of encouraging interactions between authors and users is here to stay. The collaborative and participatory potential of social media will not be fully realized, however, until individuals can effectively evaluate, use, and contribute to these sources. By incorporating social media within the scope and training of IL, librarians have much to offer in shaping an informed citizenry in this era of social media. 


\section{Notes}

1. Alison J. Head and Michael B. Eisenberg, "How Today's College Students Use Wikipedia for Course-Related Research," First Monday 15, no. 3 (2010), available online at www.firstmonday. org/htbin/cgiwrap/bin/ojs/index.php/fm/article/viewArticle/2830/2476 [accessed 3 October 2012]; Pew, "YouTube \& News: A New Kind of Visual Journalism," (2012), available online at www. journalism.org/analysis_report/youtube_news [accessed 3 October 2012].

2. Joanna Brenner, "Pew Internet: Social Networking," (2012), available online at http:// pewinternet.org/Commentary/2012/March/Pew-Internet-Social-Networking-full-detail.aspx [accessed 3 October 2012]; Amanda Lenhart, Mary Madden, Alexandra Rankin Macgill, and Aaron Smith, "Teens and Social Media" (2007), available online at http://pewinternet.org/ /media// Files/Reports/2007/PIP_Teens_Social_Media_Final.pdf.pdf [accessed 1 August 2012]; Head and Eisenberg, "How Today's College Students Use Wikipedia"; Head and Eisenberg, "How College Students Use the Web to Conduct Everyday Life Research," First Monday 16, no. 4 (2011), available online at www.firstmonday.org/htbin/cgiwrap/bin/ojs/index.php/fm/article/viewArticle/3484/2857 [accessed 3 October 2012].

3. Meredith Farkas, "Information Literacy 2.0," American Libraries (2011), available online at http://americanlibrariesmagazine.org/columns/practice/information-literacy-20 [accessed 1 August 2012]; Sonja Spiranec and Mihaela Banek Zorica, "Information Literacy 2.0: Hype or Discourse Refinement?" Journal of Documentation 66, no. 1 (2010): 140-53.

4. "Social Media," in Merriam-Webster (2012), available online at www.merriam-webster.com/ dictionary/social media [accessed 1 August 2012].

5. Andreas M. Kaplan and Michael Haenlein, "Users of the World, Unite! The Challenges and Opportunities of Social Media," Business Horizons 53, no. 1 (2010): 59-68; New Media Consortium, Horizon Report. 2012 Higher Education Edition, 2012, available online at http://net.educause.edu/ir/ library/pdf/HR2012.pdf [accessed 22 November 2012]; Nina Dohn, "Web 2.0: Inherent Tensions and Evident Challenges for Education," International Journal of Computer-Supported Collaborative Learning 4, no. 3 (2009): 343-63.

6. Brenner, "Pew Internet: Social Networking."

7. Kathryn Zickuhr, "Generations 2010" (2010), available online at http://pewinternet.org/ Reports/2010/Generations-2010.aspx [accessed 1 August 2012].

8. Aaron Smith, Lee Rainie, and Kathryn Zickuhr, "College Students and Technology" (2011), available online at http://pewinternet.org/Reports/2011/College-students-and-technology/Report. aspx [accessed 1 August 2012].

9. Paolo Gardois, Nicoletta Colombi, Gaetano Grillo, and Maria C. Villanacci, "Implementation of Web 2.0 Services in Academic, Medical and Research Libraries: A Scoping Review," Health Information and Libraries Journal 29, no. 2 (2012): 90-109; Alton Y. K. Chua and Dion H. Goh, "A Study of Web 2.0 Applications in Library Websites," Library and Information Science Research 32, no. 3 (2010): 203-11; Khalid Mahmood and John V. Richardson Jr., "Adoption of Web 2.0 in US Academic Libraries: A Survey of ARL Library Websites," Program 45, no. 4 (2011): 365-75.

10. Amanda Click and Joan Petit, "Social Networking and Web 2.0 in Information Literacy," International Information and Library Review 42, no. 2 (2010): 137-42; Lili Luo, "Web 2.0 Integration in Information Literacy Instruction: An Overview," Journal of Academic Librarianship 36, no. 1 (2010): 32-40.

11. Head and Eisenberg, "How College Students Use the Web"; Kyung-Sun Kim, Eun Young Yoo-Lee, and Sei-Ching Joanna Sin, “Social Media as Information Source: Undergraduates' Use and Evaluation Behavior," Proceedings of the ASIST Annual Meeting 48 (2011), available online at http:// onlinelibrary.wiley.com/doi/10.1002/meet.2011.14504801283/full [accessed 1 August 2012]; Sei-Ching Joanna Sin and Kyung-Sun Kim, “International Students' Everyday Life Information Seeking: The Informational Value of Social Networking Sites," Library \& Information Science Research, 35, no. 2 (2013): 107-16.

12. Peter Denning, Jim Horning, David Parnas, and Lauren Weinstein, "Wikipedia Risks," Communications of the ACM 48, no. 12 (2005): 152; Deborah J. Grimes and Carl H. Boening, "Worries with the Web: A Look at Student Use of Web Resources," College \& Research Libraries 62, no. 1 (2001): 11-22.

13. Philip M. Davis, "Effect of the Web on Undergraduate Citation Behavior: Guiding Student Scholarship in a Networked Age," Portal 3, no. 1 (2003): 41-51; Grimes and Boening, "Worries with the Web," 11-23; Miriam J. Metzger, "Making Sense of Credibility on the Web: Models for Evaluating Online Information and Recommendations for Future Research," Journal of the American Society for Information Science and Technology 58, no. 13 (2007): 2078-91.

14. Candice Dahl, "Undergraduate Research in the Public Domain: The Evaluation of NonAcademic Sources Online," Reference Services Review 37, no. 2 (2009): 155-63. 
15. James Ball and Paul Lewis, "Twitter and the Riots: How the News Spread," The Guardian, December 7, 2011, available online at www.guardian.co.uk/uk/2011/dec/07/twitter-riots-hownews-spread [accessed 1 August 2012].

16. John C. Bertot, Paul T. Jaeger, and Justin M. Grimes, "Using ICTs to Create a Culture of Transparency: E-Government and Social Media as Openness and Anti-Corruption Tools for Societies," Government Information Quarterly 27, no. 3 (2010): 264-71; Ramesh Srinivasan, "Indigenous, Ethnic and Cultural Articulations of New Media," International Journal of Cultural Studies 9, no. 4 (2006): 497-518.

17. David Bawden, "Information and Digital Literacies: A Review of Concepts," Journal of Documentation 57, no. 2 (2001): 218-59; Shirley J. Behrens, "A Conceptual Analysis and Historical Overview of Information Literacy," College and Research Libraries 55, no. 4 (1994): 309-22; James Elmborg, "Critical Information Literacy: Implications for Instructional Practice," Journal of Academic Librarianship 32, no. 2 (2006): 192-99; James W. Marcum, "Rethinking Information Literacy," Library Quarterly 72, no. 1 (2002): 1-26; Kimmo Tuominen, Reijo Savolainen, and Sanna Talja, "Information Literacy as a Sociotechnical Practice," Library Quarterly 75, no. 3 (2005): 329-45; Sheila Webber and Bill Johnston, "Conceptions of Information Literacy: New Perspectives and Implications," Journal of Information Science 26, no. 6 (2000): 381-97; Thomas P. Mackey and Trudi E. Jacobson, "Reframing Information Literacy as a Metaliteracy," College E Research Libraries 72, no. 1 (2011): 62-78; Christine Pawley, "Information Literacy: A Contradictory Coupling," Library Quarterly 73, no. 4 (2003): 422-52.

18. Michelle Dunaway, "Web 2.0 and Critical Information Literacy," Public Services Quarterly 7, no. 3-4 (2011): 149-57; James Elmborg, “Critical Information Literacy," 192-99.

19. Carolyn Carpan, "Introducing Information Literacy 2.0," College E Undergraduate Libraries 17, no. 1 (2010): 106-13; Farkas, "Information Literacy 2.0"; Spiranec and Zorica, "Information Literacy 2.0," 140-53; Kimmo Tuominen, “Information Literacy 2.0," Signum, no. 5 (2007): 6-12.

20. Henry Jenkins, Confronting the Challenges of Participatory Culture: Media Education for the 21st Century (Chicago: John D. and Catherine T. MacArthur Foundation, 2006), available online at http://digitallearning.macfound.org/atf/cf/\%7B7E45C7E0-A3E0-4B89-AC9C-E807E1B0AE4E\%7D/ JENKINS_WHITE_PAPER.PDF [accessed 14 December 2012]; Henry Jenkins, Combating the Participation Gap: Why New Media Literacy Matters, UC Berkley School of Information (2008), available online at www.ischool.berkeley.edu/newsandevents/events/dls20080206 [accessed 14 December 2012]; Renee Hobbs, "Debates and Challenges Facing New Literacies in the 21st Century," in International Handbook of Children, Media and Culture, eds. Sonia M. Livingstone and Kirsten Drotner (London: Sage, 2008), 431-47; Danah Boyd, "Whether the Digital Era Improves Society Is up to Its Users - That's Us," The Guardian, April 21, 2012, available online at www.guardian. co.uk/commentisfree/2012/apr/21/digital-era-society-social-media [accessed 14 December 2012].

21. Mackey and Jacobson, "Reframing Information Literacy," 62-78; Donna Witek and Teresa Grettano, "Information Literacy on Facebook: An Analysis," Reference Services Review 40, no. 2 (2012): 242-57.

22. Joy L. Austria, "Developing Evaluation Criteria for Podcasts," Libri: International Journal of Libraries \& Information Services 57, no. 4 (2007): 179-208; Laurie M. Bridges, "Librarian as Professor of Social Media Literacy," Journal of Library Innovation 3, no. 1 (2012): 48-65; Cornell University, "Digital Literacy Resource," available online at http://digitalliteracy.cornell.edu/ [accessed 14 December 2012]; Tracy Mitrano, "“It Takes Only a Generation': Information Literacy in the Digital Age," available online at www.it.cornell.edu/policies/publications/generation.cfm [accessed 14 December 2012]; Witek and Grettano, "Information Literacy on Facebook," 242-57.

23. Association of College and Research Libraries, "Information Literacy Competency Standards for Higher Education," available online at www.ala.org/acrl/standards/informationliteracycompetency [accessed 1 August 2012].

24. Amanda Spink and Charles Cole, "Human Information Behavior: Integrating Diverse Approaches and Information Use," Journal of the American Society for Information Science and Technology 57, no. 1 (2006): 25-35.

25. Mackey and Jacobson, "Reframing Information Literacy," 62-78.

26. Alison J. Head, "Information Literacy from the Trenches: How Do Humanities and Social Science Majors Conduct Academic Research?" College and Research Libraries 69, no. 5 (2008): 427-45; Kyung-Sun Kim and Sei-Ching Joanna Sin, "Selecting Quality Sources: Bridging the Gap between the Perception and Use of Information Sources," Journal of Information Science 37, no. 2 (2011): 178-88.

27. Head and Eisenberg, "How College Students Use the Web."

28. Sook Lim, "How and Why Do College Students Use Wikipedia?" Journal of the American Society for Information Science and Technology 60, no. 11 (2009): 2189-202; Sook Lim and Christine Simon, "Credibility Judgment and Verification Behavior of College Students Concerning Wikipedia," First Monday 16, no. 4 (2011), available online at http:/firstmonday.org/htbin/cgiwrap/bin/ ojs/index.php/fm/article/view/3263/2860 [accessed 1 August 2012]; Eti Yaari, Shifra BaruchsonArbib, and Judit Bar-Ilan, "Information Quality Assessment of Community Generated Content: A User Study of Wikipedia," Journal of Information Science 37, no. 5 (2011): 487-98. 
29. Alison J. Head and Michael B. Eisenberg, "What Today's College Students Say about Conducting Research in the Digital Age," (2009), available online at http://projectinfolit.org/pdfs/ PIL_ProgressReport_2_2009.pdf [accessed 1 August 2012].

30. Head and Eisenberg, "How College Students Use the Web."

31. Rich Gazan, "Social Q\&A," Journal of the American Society for Information Science and Technology 62, no. 12 (2011): 2301-12; Pnina Shachaf, "Social Reference: Toward a Unifying Theory," Library and Information Science Research 32, no. 1 (2010): 66-76; Chirag Shaha, Sanghee Oh, and Jung Sun Oh, "Research Agenda for Social Q\&A," Library and Information Science Research 31, no. 4 (2009): 205-09.

32. Head and Eisenberg, "How College Students Use the Web."

33. Sei-Ching Joanna Sin, Kyung-Sun Kim, Jiekun Yang, Joung-A Park, and Zac T. Laugheed, "International Students' Acculturation Information Seeking: Personality, Information Needs and Uses," Proceedings of the ASIST Annual Meeting 48 (2011), available online at http://onlinelibrary. wiley.com/doi/10.1002/meet.2011.14504801222/full [accessed 14 December 2012].

34. Soo Young Rieh and David R. Danielson, "Credibility: A Multidisciplinary Framework," in Annual Review of Information Science and Technology, ed. B. Cronin (Medford, N.J.: Information Today, 2007), 307-64.

35. Soojung Kim, "Questioners' Credibility Judgments of Answers in a Social Question and Answer Site," Information Research 15, no. 2 (2010); Lim and Simon, "Credibility Judgment"; Reijo Savolainen, "Judging the Quality and Credibility of Information in Internet Discussion Forums," Journal of the American Society for Information Science and Technology 62, no. 7 (2011): 1243-56.

36. Kim, "Questioners' Credibility Judgments."

37. Kim and Sin, "Selecting Quality Sources," 178-88.

38. Ibid.

39. Grimes and Boening, "Worries with the Web," 11-23; Miriam J. Metzgera, Andrew J. Flanagina, and Lara Zwarunb, "College Student Web Use, Perceptions of Information Credibility, and Verification Behavior," Computers and Education 41, no. 3 (2003): 271-90.

40. Metzger, "Making Sense of Credibility," 2078-91.

41. Kim, Yoo-Lee, and Sin, "Social Media as Information Source."

42. Zickuhr, "Generations 2010."

43. Aaron Smith and Joanna Brenner, "Twitter Use 2012" (2012), available online at http:// pewinternet.org/ /media//Files/Reports/2012/PIP_Twitter_Use_2012.pdf [accessed 3 October 2012].

44. Hsin-liang Chen, "The Perspectives of Higher Education Faculty on Wikipedia," Electronic Library 28, no. 3 (2010): 361-73; Jeffrey R.Young, “Wikipedia Founder Discourages Academic Use of His Creation," The Chronicle of Higher Education (2006), available online at https://chronicle.com/ blogs/wiredcampus/wikipedia-founder-discourages-academic-use-of-his-creation/2305 [accessed 1 August 2012].

45. Head and Eisenberg, "How Today's College Students Use Wikipedia"; Ericka MenchenTrevinoa and Eszter Hargittai, "Young Adults' Credibility Assessment of Wikipedia," Information Communication and Society 14, no. 1 (2011): 24-51.

46. Klaus Wannemacher, "Experiences and Perspectives of Wikipedia Use in Higher Education," International Journal of Management in Education 5, no. 1 (2011): 79-92.

47. William Cronon, "Scholarly Authority in a Wikified World," (2012), available online at www.historians.org/Perspectives/issues/2012/1202/Scholarly-Authority-in-a-Wikified-World.cfm [accessed 3 October 2012].

48. Head and Eisenberg, "How Today's College Students Use Wikipedia."

49. Head and Eisenberg, "How College Students Use the Web"; Brendan Luyt, Chia Zuhaila Bte Chia Zainal, Olivia Victoria Petines Mayo, and Tan Siow Yun, "Young People's Perceptions and Usage of Wikipedia," Information Research, no. 4 (2008), available online at http://informationr. net/ir/13-4/paper377.html [accessed 1 August 2012].

50. Web of Deceit: Misinformation and Manipulation in the Age of Social Media, ed. Anne P. Mintz (Medford, N.J.: Information Today, 2011); Myle Ott, Claire Cardie, and Jeff Hancock, "Estimating the Prevalence of Deception in Online Review Communities," in Proceedings of the 21st International Conference on World Wide Web (Lyon, France: ACM, 2012); David Streitfeld, "In a Race to Out-Rave, 5-Star Web Reviews Go for \$5," New York Times, August 19, 2011, available online at https://www. nytimes.com/2011/08/20/technology/finding-fake-reviews-online.html [accessed 3 October 2012].

51. Center for Social Media, "The Code of Best Practices in Fair Use for Media Literacy Education," available online at www.centerforsocialmedia.org/fair-use/related-materials/codes/code-bestpractices-fair-use-media-literacy-education [accessed 14 December 2012]; Ramona L. Islam and Lisa Anne Murno, "From Perceptions to Connections: Informing Information Literacy Program Planning in Academic Libraries through Examination of High School Library Media Center Curricula," College \& Research Libraries 67, no. 6 (2006): 491-514; Lili Luo, "Web 2.0," 32-40; Creative Commons, "About," available online at https://creativecommons.org/about [accessed 1 August 2012]. 